\title{
General Attitudes, Cultural Significance and Health Risks Associated with Body Arts among Ewe Youth in the Volta Region of Ghana
}

\author{
Mary Ama Agbezuge1, Daniel Kwabena Danso1, Dickson Adom²* \\ ${ }^{1}$ Department of Fashion Design and Textiles Education, Akenten Appiah-Menka University of Skills Training and Entrepreneurial \\ Development, Kumasi, Ghana \\ ${ }^{2}$ Department of Educational Innovations in Science and Technology, Kwame Nkrumah University of Science and Technology, \\ PMB University Post Office, Kumasi, Ghana \\ Email: *adomdick2@gmail.com, *dickson.adom@knust.edu.gh
}

How to cite this paper: Agbezuge, M. A., Danso, D. K., \& Adom, D. (2022). General Attitudes, Cultural Significance and Health Risks Associated with Body Arts among Ewe Youth in the Volta Region of Ghana. Art and Design Review, 10, 1-17.

https://doi.org/10.4236/adr.2022.101001

Received: November 23, 2021

Accepted: December 11, 2021

Published: December 14, 2021

Copyright $\odot 2022$ by author(s) and Scientific Research Publishing Inc. This work is licensed under the Creative Commons Attribution International License (CC BY 4.0).

http://creativecommons.org/licenses/by/4.0/

\begin{abstract}
The purpose of the study was to assess the general attitudes, cultural significance and health risks associated with body arts on the Ewe youth in the Volta Region of Ghana. The descriptive research design under the quantitative research approach was adopted for the study. The population for this study was made up of 125 Ewe youths in the Volta Region of Ghana who was sampled using the random sampling method. Researcher-designed questionnaire was the main data collection tool. The analysis was done quantitatively using descriptive statistics in the form of frequencies and percentages with the aid of the SPSS software. The findings revealed that the majority of the respondents (95\%) said that Ewes are concerned about the cultural significance of body arts as indicators of social status, self-esteem, beauty, ethnic and religious identity, as well as spiritual and medicinal protection. Regarding the health risks associated with body arts, it was found that $97 \%$ stated that body decorating can lead to body cancer and allergic reaction, $83 \%$ agreed that body arts can cause pain and excessive bleeding, 95\% said body arts can cause nerve damage, $68 \%$ said body arts can cause life-threatening bacterial infections and $79 \%$ indicated that body arts can lead to blood-borne virus infections like Hepatitis B and HIV. The study contends that a greater section of the Ewe youth has extensive knowledge regarding the cultural significance and health risks of body arts. However, knowledge on the safer approaches to body arts must be carried out through well-planned public education programs organized by the Ghana Health Service especially among the youth in Ghana.
\end{abstract}




\section{Keywords}

Body Arts, Culture, Ewe, Health Risks Of Body Arts, Voltarian Culture

\section{Introduction}

Body arts refer to the making of designs on the body or the wearing of special items on the body as a form of visual language (Glover-Thomas, 2020; Schildkrout, 2001). Body arts include various forms of modifications on the body such as painting, tattooing, piercing, subdermal implants, surgical modifications, tongue bifurcation or forking, scalpelling, etc. for purposes of personal adornment, cultural affiliation, medicinal, entertainment, and so forth (Korn et al., 2021; Clerici \& Meggiolaro, 2011). Body arts have gained increasing popularity worldwide. Body art is increasingly accepted by all social classes and age groups, but especially by youths (Stirn, 2013). In Western society, body arts have become mainstream activities among adolescents (12 to 18 years of age) and young adults (18 to 25 years of age) (Montgomery \& Parks, 2014). Prevalence of body art in these age groups varies by country and setting, ranging from $6.5 \%$ to $56 \%$ for pierced subjects, and from $4.5 \%$ to $24 \%$ for body arts. In Italy, three studies have been carried out on adolescents in Tuscany and the Veneto region. Data show that $20 \%$ to $35 \%$ of adolescents reported having a body art, while $4 \%$ to $6.3 \%$ of students had tattoos (Stirn, 2013). As the prevalence of body art has increased, adverse health risks associated with these practices have been documented. Infectious complications brought on by lack of proper care of body art sites are also possible (Montgomery \& Parks, 2014). Tattoos and body piercing as expressions of individuality, group affiliation or belonging, resistance and control have become a normal and popular practice among adolescents.

These practices have potential infectious and non-infectious health risks, medical complications and negative social consequences (Quist, 2008). Long-term effects cannot be predicted. Exposure to tattoo and body piercing through environmental and cultural influences can encourage participation in body art practices, sometimes without awareness of the risks involved (Frings, 2014). The most common complications that result from arts are skin infections and allergic reactions to the tattoo ink. Extensive skin puncturing can result in bleeding and prolonged leaking of serosanguinous fluid (Frings, 2014). The use of needles and other piercing instruments allows the mucocutaneous transmission of infectious diseases (Frings, 2014). These can range from local to systemic infections (e.g., osteomyelitis, toxic shock syndrome, and bacteremia), as well as to life-threatening ones (e.g., septic arthritis, acute glomerulonephritis, endocarditis, and hepatitis). Pyoderma infections can include temporary inflammation at the site of needle puncture, superficial infections such as impetigo and ecthyma, and deeper infections such as cellulitis, erysipelas, and furunculosis. Unsterile equipment and needles can transmit infectious diseases such as hepatitis (Quist, 2008). Human 
immunodeficiency virus is theoretically transmissible this way, but no cases of HIV infection caused by arts have been documented. Skin reactions to arts include aseptic inflammation and acquired sensitivity to tattoo ink, especially red ink, but also to chromium in green ink, cadmium in yellow ink, and cobalt in blue ink (Frings, 2014). Modifying your body with piercings also carries a measure of risk, such as the risk for a bacterial infection. Some people develop an abscess after getting a piercing. This pus-filled mass can develop around the piercing (Frings, 2014). This is a serious side effect. If left untreated, there's the risk of sepsis or blood poisoning. Sepsis is a life-threatening response to an infection that can result in organ failure and death. Symptoms of blood poisoning include a high fever, chills, a fast heartbeat, and rapid breathing. Infections are more common with mouth and nose piercings because these areas contain more bacteria (Quist, 2008).

Given the widespread practice of body arts, and the high number of potentially associated complications, it is important to inform consumers about possible hazards and the management of complications during and after these practices (Montgomery \& Parks, 2014). However, youth often lack awareness of health risks, and patronize operators who ignore or do not apply risk-control measures. In 2008, the Italian Ministry of Health issued safe practice guidelines that apply to tattoo and body arts facilities, as well as beauty shops (Frings, 2014). Many regions have since adopted these and established local regulations, and many professional body artists and tattooists have organized in association with health workers to promote safe body modification (Montgomery \& Parks, 2014). Nonetheless, unlicensed and untrained personnel practicing body art out of unregulated shops, jewelry stores or at home can still provide youths with ready access to these services (Stirn, 2013). The majority of surveys on youths' knowledge of risks related to body art practices have been carried out among university students; those that address adolescents' attitudes are infrequent (Montgomery \& Parks, 2014). To highlight possible differences among age groups, the present study investigated experiences with and knowledge of possible health consequences of arts and piercing by comparing two samples of students, those from high schools and universities in the province of Naples (Montgomery \& Parks, 2014).

A gruesome list of illnesses and health problems contracted by people who have had body arts was released in an effort to raise awareness about the dangers of body arts. Up to half of all body arts lead to acute infections which require medical treatment, and there were many body art-related deaths in Africa and Europe in 2016 (Keita \& Grinch, 2017). They added that little was known about the chemical structure and toxicity of many of the dyes used in arts and warned that many people were effectively injecting car paint into their skins. When health standards are disregarded people who are anxious to decorate and personalise their body with dye have had to pay dearly for bad practices (Quist, 2015). These practices can bring about a lot of infections which are mostly not known 
to the youths in most cases especially in the Volta Region of Ghana. Hence the aim of this study was to assess the general attitudes, cultural and health impacts of body arts on the Ewe youth in the Volta Region of Ghana. The research questions for the study were:

1) What are the general attitudes of the Ewe youth towards body arts in the Volta Region of Ghana?

2) What are the health risks of body arts among the Ewe youth in the Volta Region of Ghana?

3) What is the cultural significance of body arts among the Ewe youth in the Volta Region of Ghana?

\subsection{Purposes of Body Arts}

Body marks are the main aspect of body arts that involves the deliberate creation of temporary or permanent marks on the body for cultural, political, entertainment and other reasons (Ebeheakey \& Kquofi, 2018). It includes Body marks is an aspect of body arts that has a long history. Body marks date back decades ago from marks made on fertility dolls to tattoos of tribal hierarchy (Ozongwu, 2013). The history of body marking started in Africa between 8000 B. C. - 5000 B. C. when several markings were seen on some images discovered in Tassili in the Sahara (Ankrah, 2015). There have been different tribes practicing body marks. Most of these tribes, according to Von Luschan's scale, fall beneath the equator. This is supported and further simplified by Parra et al. (2013) that, people living close to the equator are darkly pigmented (have darker skin) and those living near the pole are lightly pigmented (have lighter skin). Some of these tribes with darkly pigmented tribesmen still practice body marks while it remains a dying practice for other tribes. With time, different ways of marking were adopted by other tribes for different reasons. Some ethnic groups use body marks as a source of aesthetic or beautification and protection therapy (Uzobu, Olomu, \& Ayinmoro, 2014). Irrespective of how it may seem that body marking may have a single common purpose or reason which is for identification. Body marks are used mainly to differentiate ethnic groups, they vary according to the customs and preferences of the lineage, village or family (Ibiyemi, 2014).

Among some tribes, beautification is one of the reasons and purposes for which body marks are made. Decorative or beautification marks can be found in both males and females but most popular among females. Most often, decorative marks are obtained by females in their teen years. However, some parents make decorative marks on their infants' face after or during their naming ceremony (Ibrahim, 2018). Most people belong to tribes that do not have specific marking, yet they choose to be scarred for the purpose of beautification (Ibrahim, 2018). It is important to indicate that some traditional markers have had situations where adults request for these marks because they found them attractive. In the past, a person who did not receive body marks may have been teased and not accepted by other members of their ethnic group because they were termed not beautiful and unattractive. It is suggested that generally body marks were made for the 
purpose of beautification and that, according to some traditional surgeons, people tend to admire these marks and find the bearers attractive; this is due to the belief that such marks enhance beauty (Falola \& Ngom, 2019). In Sudan, facial marking is a common practice that is seen on the faces of tribesmen and this not only gives identity to the tribe but beautifies the women as well. Scars are thought to beautify the body and this usually begins from childhood for an African child (especially girls). This takes place during rituals at childbirth, a celebration of the onset of puberty and the first menstrual cycle (Falola \& Ngom, 2019).

Scarification and body marks as forms of body arts are viewed as a test of courage (Murano, 2014). In African traditional medical parlance, facial markings connote treatment of illness for children. In this, traditional healers make incisions on the faces or body of children whom ailments like convulsion, pneumonia, and measles are infected and need to be treated (Cullivan, 2018). The willingness of a woman to go through the pain of body marking was an indication of her emotional maturity and willingness to bear children. Often, the first scars a young woman receives are those on her abdomen, emphasizing the role of child bearing (Murano, 2014). Some marks indicate that the wearer, especially from a particular family or royal lineage has passed through initial initiation into the highest society thus, marking the wearer as nobility (Cullivan, 2018). In summary, the purposes of body arts are varied. They include beautification, entertainment, physical or spiritual medicinal reasons, physical signs of cultural affiliations, test of courage and determining social status in the society.

\subsection{Perceptions of Body Arts among Different Cultures}

Body arts has evolved through an enormous cultural exchange, beginning with conventions of body arts during the ancient period where it was seen as an ethnic means of identification in some cultures and correctional means in other cultures like Japan and Europe (Ankirskiy, 2014). With differences in perception and stereotypes based on cultural beliefs and religion, it is therefore critical to understand how these differences pertain in order to better appreciate the context-driven stereotype about body arts. One of the most difficult terms to define in sociology and social psychology is the concept of culture. There has been seemingly conscious effort to have a consensus on how to define culture over the years. Many definitions have been provided by different scholars. One of such definitions is Tyler's 1870 explanation of what culture entails. To Tyler (as cited in Avruch, 2018: p. 6), "Culture... is that complex whole which includes knowledge, belief, art, morals, law, custom, and any other capabilities and habits acquired by man as a member of the society".

On the other hand, morality has been defined as conscience, as a set of cultural rules of social action which has been internalized by a group of people (Kohlberg, 2014). Inferring from the definitions of morality and culture by Kohlberg and Tyler respectively, it is apparent that the two are intertwined if not the same. Therefore, it is impossible to talk about culture without reference to morality 
and vice versa. Morality is the central point for defining social relationships and development in our society (Kohlberg, 2014). Referring to the definitions of culture and morality, it is possible to say culture and morality is embedded in us from our social environment from which we learn and develop attitudes and beliefs. These attitudes and beliefs we imbibe in us serve as a means through which we perceive things around us. In relation to body arts, certain cultures might be more receptive than others. For example, in the Maori culture (New Zealand), the moko-facial body art was a form of family identification and was used in signing documents (Bell, 2019). Unlike the people of New Zealand, body art was a tribal customary rite for the people of Ainu in Japan which signified religious expression and sexual maturity (Ankirskiy, 2014). Ainu women mostly had the body arts around their cheeks, lips, eyebrows and forehead. In Africa, history has it that body art started from the people of Egypt and was common to women as a form of social status or punishment. In Africa, body art was seen as an affiliation to an ethnic group, social status of the bearer, and as a means of protecting against evil spirits.

However, with North Africa dominated by Islamic religion, some strict Muslims see body art as unholy. It is difficult if not impossible to obtain data on the level of acceptance in Africa, even though body modification is seen especially among the younger generation. However, Nigeria is reported to have its younger population accepting and wearing body arts. Ezeibekwe et al. (2016) believes body modification have been widely consumed among cultures in Nigeria with majority being the youth. In other parts of Africa, like the Ko tribe (Burkina Faso), Yoruba tribe (Nigeria) body modification has metamorphosed into different forms of scarification, which is seen as part of their traditional practices (Brooks, 2017). It will be unfair to talk about body arts without reference to other cultures that upheld the practice. Body arts appear to be thriving in the United States as well, and this is as a result of social media's propagation. A survey from the US conducted by Statista in 2015 on people's attitude towards body art revealed that $54 \%$ did not perceive any difference between body modified and non-body modified when it comes to deviance. In addition, $40 \%$ stated they see body modified person as more deviant whereas $6 \%$ stated they did not see them as deviant (Statista, 2015).

Evidence from studies conducted gives an indication that perception towards body art in the Western world has improved compared to some three decades ago (Ankirskiy, 2014). In New Zealand, body arts are generally accepted, and Pacific/Maori body art seems to become a very common preference in the world. However, there still are instances when tattooing is frowned upon, such as the incident when a woman was dismissed from an interview for a hostess position at Air New Zealand because she had a body art with a Maori motif on her forearm. The perception of the general population, especially the older population is that they do not have a relaxing attitude towards traditional body art (Tokyo Times, 2013). On the other hand, the younger generation of the Japanese seem to have a more positive and relaxed stance on body arts. A survey conducted by 
Ankirskiy (2014) indicated that the majority of Japanese respondents are not wearing body art and do not have the intention to acquire one. The discussion shows that the perceptions of body arts are different among cultures and religions. While some cultures and religions allow them for spiritual, emotional, and psychological reasons, others object them for these same reasons.

\subsection{Body Arts: Stigma, Prejudice and Discrimination}

A noticeable theme in body arts research has been the negative consequences suffered by persons with body arts. Research on body arts has indicated how persons with body arts mostly suffer from stigma, prejudice and discrimination (Ellis, 2015; Timming, 2015). There seems to be some level of outright disapproval of body arts at all levels of endeavor. Timming and Perrett (2017) in their study compared various forms of body art genres and realized that body art depicting nudity and violence was related to lower levels of trustworthiness, whereas those depicting floral and tribal genres had the highest level of trustworthiness and neutral stance on stance of trustworthiness respectively.

Contrary to the generally held view, using 14 colleges and universities from the United States, Totten, Lipscomb, and Jones (2009) reported both negative and positive attitude associated with persons wearing body arts. Although majority of the respondents did not have any negative perception about body arts, they believed that society portrayed persons with body arts negatively. Totten et al. (2009) however reported that over $40 \%$ of respondents had some form of body arts which possibly could be the reason for the perception. Interestingly, even though expected of such a population, younger respondents saw body arts as aesthetically appealing compared to older respondents. In addition, majority of respondents agreed that body arts should be done in moderation and denounced the assertion that body arts are connected to drug abuse, promiscuity and bad image. These experiences of stigma, prejudice and discrimination that persons with body arts go through are not only limited to the society but to the work environment as well.

Some studies have reported that persons with body arts experience discrimination at the workplace during the process of recruitment, evaluation and promotion. Summers et al. (2018) reported key findings that lead to stigma within organisations. Personal characteristics like body arts, obesity, sexual orientation, and religion are seen to be stigmatizing and may result in unequal access to opportunities within organization. In line with this argument, Arndt, McCombs, Tolle and Cox (2017), revealed that dentists were less likely to employ hygienists with body arts. The major concern of these hygienists as reported was the impact body arts will have on the image of the profession. Beyond these studies that have been discussed, there have been outstanding authors who have also offered current literature to the subject matter in relation to the experiences of body modified persons. One of such authors is Andrew Timming. Timming (2015) adopted a qualitative approach to understand the experiences of hiring managers and body arts respondents. The study reported that VBM constitutes a major 
setback in an applicant's chance of being hired with themes relating to the negative acceptance of body arts.

Thus, employees or job applicants adorned with body arts suffered prejudice and stigma as a result of their body arts. Interestingly, the study also reported other themes played a role or affected one's possibility of being hired. For example, he stated that the type of industry, type of body arts, genre of the body arts and whether the job is a customer facing type of job. Similar to Timming's work, Ellis (2015) in his work on body arts explores the experiences of body arts employees and potential body arts applicants via an online discussion platform. Narrating issues in relation to job search and experiences at work, it was found that recurrent in the discussion were issues of prejudice, stigma and discrimination. Considering the nature of prejudice and stereotype that body modified employees and potential job applicants' experience, some studies have distinguished between customer facing and noncustomer facing jobs to help understand how some jobs are receptive to body arts. In what seem to be a mixed reaction, Fountain-Jagodzinski (2014) was to examine stereotypes within the context of enlistment into organisations. The study explored the perspectives of hiring managers and contrasting those perspectives with current court cases and corporate culture or policies.

To understand the hiring managers' perspective of the issue, interviews were conducted and the perspective showed that most of them were indifferent (had neutral stance), thus hiring managers were neither liberal nor conservative about the issue of body arts at work. Nonetheless, if a decision is needed to be made where employees would have to expose their body arts, hiring managers often sided with conservative perspective. In contrast, Barrett and Aspen (2009) attempted to design a quantitative study that sought to understand the perception of professional hiring managers in offering jobs to body arts applicants. Even though the interview process entails an adherence to conservative professionalism during the recruitment process, it was reported that hiring managers would hire persons with body arts. In addition to this revelation, hiring managers disagreed that persons with body arts were abnormal, criminals, mentally ill, lesbian or gay and had low economic status.

\section{Methods}

\subsection{Research Design}

The study was conducted between October 2019 to December 2020 in the Volta Region of Ghana. The study employed the descriptive research design under the quantitative research approach.

\subsection{Study Participants}

The population for this study was made up of the 125 Ewe youth in the Volta Region of Ghana who were sampled through the random sampling method. This sampling method was employed to give equal chance to all the Ewe youth in the region to partake in the study (Shwarz, 2011). This sample size ensured that data 
saturation was reached.

\subsection{Survey Instruments}

Self-designed questionnaire was the main instrument employed to collect data from the study participants (Punch, 2013). It was used because it is one of the most efficient instruments used in survey studies because they provide viable means of statistically quantifying the data collected. The response rate to the answering of the questionnaire administered was $96 \%$. The questionnaire was based on the three main aspects of the study which were the general attitudes of body arts, the health impacts of body arts and the cultural impacts of body arts. The introductory section of the questionnaire detailed the purpose of the study and solicited for the socio-demographic data of the study participants. After the development of the questionnaire, it was sent to four experts in quantitative research in the university for vetting its credibility. Their suggestions were factored into the final draft of the questionnaire. It was further pre-tested on fifteen Ewe youth. In each youth age range (under 20 years, 21 years to 29 years, and $30-35$ years) five were selected. The questionnaire was further improved after the pilot studies before finally administering it among the study participants for the actual study. The questionnaire developed was in consonance with the private legislation under the Data Protection Act of Ghana, 2012 (Act 843).

\subsection{Ethical Considerations}

An approval was given by the research ethics committee in the Department of Fashion Design and Textiles Education, Akenten Appiah-Menka University of Skills Training and Entrepreneurial Development, Ghana. All the study participants were asked to sign a written consent form agreeing to voluntarily partake in the study. They were assured of the protection of their personal identities and that their views expressed were to be used for research purposes only.

\subsection{Data Analytical Procedure}

The analysis was done quantitatively using descriptive statistics. The quantitative data garnered which were for the categorical variables were presented in the form of frequencies and percentages while drawing inferences from the literature already reviewed in chapter two of this study. The obtained data were coded and analyzed systematically using Jamovi version 1.22.2 statistical package.

\section{Results}

The presentation and analysis of the results of the study is based on 120 respondents out of the 125 respondents who form the sample size.

Table 1 indicates that 154 respondents representing $70 \%$ were males while 66 respondents representing 30\% were females. Moreover, 78 respondents representing $35.5 \%$ were between the age ranges 20 - 30 years, 89 respondents representing $40.4 \%$ were between the age category 31 - 35 years, 53 respondents representing $24.1 \%$ were below 20 years. 
Table 1. Demographic information of respondents.

\begin{tabular}{ccc}
\hline & Frequency & Percent \\
\hline Male & 154 & 70 \\
Female & 66 & 30 \\
Total & 220 & 100.0 \\
Age of respondents & & \\
Under 20 years & 53 & 24.1 \\
$20-30$ years & 78 & 35.5 \\
$31-35$ years & 89 & 40.4 \\
Total & 220 & 100.0 \\
\hline
\end{tabular}

Source: Field study (2019), n-220.

\subsection{The General Attitudes of Ewe Youth toward Body Arts}

The study aimed at deciphering the attitudes of Ewes toward body arts and the views of the respondents are presented in Table 2. The data collected showed that 114 of the total respondents representing 95\% said that Ewes are concerned about the cultural and moral impact of body arts while the remaining 6 of them (5\%) said they disagree. Few of the total respondents (32) representing 27\% agreed that Ewes opt for sustainable body arts instead of low-cost ones, 81 of them $(68 \%)$ disagreed while 6 of the respondents $(5 \%)$ indicated that they were not sure.

Ninety-five (95) of them representing 79\% said Ewes put high priority on body arts development but few of them (15) representing $13 \%$ said no and the remaining 10 representing 8 said they are not sure of this. Again, 96 of them representing $80 \%$ said Ewes neglect foreign body art styles that can negatively impact on the youth, 20 respondents representing 17\% disagreed to this and 4 of them representing 3\% said they are not sure. Finally, 110 of them representing $92 \%$ said Ewes prioritize ethical body art styles but 8 respondents representing $6 \%$ disagreed to this and the remaining 2 of the respondents said they are not sure of this.

\subsection{Health Risks Associated with Body Arts among Ewe Youth in the Volta Region of Ghana}

Data in Table 3 shows that 117 of the total respondents representing 97\% stated that body decorating can lead to body cancer and allergic reaction while 2 of them representing $2 \%$ disagreed but the remaining 1 of them representing $1 \%$ said he is not sure of this. One hundred (100) of the respondents representing $83 \%$ agreed that body arts can cause pain and excessive bleeding, 12 of them representing $10 \%$ disagreed to this but 10 representing $8 \%$ said they are not sure. Eighty-two (82) of the respondents representing $68 \%$ said body arts can cause life threatening bacterial infections but 20 of them representing $17 \%$ disagreed to 
Table 2. General attitudes of ewe youth toward body arts.

\begin{tabular}{ccccccc}
\hline Variable & Agree & $\%$ & Disagree & $\%$ & Not Sure & $\%$ \\
\hline $\begin{array}{c}\text { Ewes are concerned about the cultural } \\
\text { and moral impact of body arts }\end{array}$ & 114 & 95 & 6 & 5 & - & - \\
$\begin{array}{c}\text { Ewes opt for sustainable body arts } \\
\text { instead of low-cost ones }\end{array}$ & 32 & 27 & 81 & 68 & 6 & 5 \\
$\begin{array}{c}\text { Ewes put high priority on } \\
\text { body arts development }\end{array}$ & 95 & 79 & 15 & 13 & 10 & 8 \\
$\begin{array}{c}\text { Ewes neglect foreign body art styles that } \\
\text { can negatively impact on the youth }\end{array}$ & 96 & 80 & 20 & 17 & 4 & 3 \\
\begin{tabular}{c} 
Ewes prioritize ethical body art styles \\
\hline
\end{tabular} & 110 & 92 & 8 & 6 & 2 & 2 \\
\hline
\end{tabular}

Source: Field study (2019), n-220.

Table 3. Health risks associated with body arts.

\begin{tabular}{ccccccc}
\hline Variable & Agree & $\%$ & Disagree & $\%$ & Neutral & $\%$ \\
\hline $\begin{array}{c}\text { Body decorating can lead to } \\
\text { body Cancer and allergic reaction }\end{array}$ & 117 & 97 & 2 & 2 & 1 & 1 \\
Pain and excessive bleeding & 100 & 83 & 12 & 10 & 8 & 7 \\
$\quad$ Can cause nerve damage & 114 & 95 & 4 & 3 & 2 & 2 \\
$\begin{array}{c}\text { Life threatening bacterial infections } \\
\begin{array}{c}\text { Blood-borne virus infections } \\
\text { like Hepatitis B and HIV }\end{array}\end{array}$ & 82 & 68 & 20 & 17 & 18 & 15 \\
\hline
\end{tabular}

Source: Field study (2019), n-220.

this and 18 representing $15 \%$ said they are not sure of this. Also, 94 of the total respondents representing $79 \%$ indicated that body arts can lead to blood-borne virus infections like Hepatitis B and HIV while 16 of them representing 13\% disagreed and 10 representing $8 \%$ said they are not sure.

\subsection{Cultural Significance of Body Arts among Ewe Youth in the Volta Region of Ghana}

The results shown in Table 4 illustrates that almost all of the respondents 119 representing $99 \%$ agreed that indigenous body arts add beauty to the individual, only 1 of them representing $1 \%$ said that he is not sure. Majority of the respondents 115 representing $96 \%$ agreed that use of body arts help to preserve rich Voltarian culture, 1 of them representing $1 \%$ disagreed while the remaining 4 said they are not sure.

Eighty-four (84) of them representing 70\% agreed that the use of body arts builds self-esteem, another 24 of them representing $20 \%$ disagreed and 10 of them also said they do not know of this. Forty-eight (48) of them representing $40 \%$ agreed that beautiful body arts enhance tourism in the Volta region, but majority of them representing $58 \%$ disagreed and 2 of them also said they do not 
Table 4. Cultural significance of body arts.

\begin{tabular}{|c|c|c|c|c|c|c|}
\hline Variable & Agree & $\%$ & Disagree & $\%$ & Neutral & $\%$ \\
\hline Body arts add beauty to the individual & 119 & 99 & - & - & 1 & 1 \\
\hline $\begin{array}{l}\text { Use of body arts help to preserve } \\
\text { rich Voltarian culture }\end{array}$ & 115 & 96 & 1 & 1 & 4 & 3 \\
\hline Use of body arts build self-esteem & 84 & 70 & 24 & 20 & 12 & 10 \\
\hline $\begin{array}{l}\text { Beautiful body arts enhance tourism } \\
\text { in the Volta region }\end{array}$ & 48 & 40 & 70 & 58 & 2 & 2 \\
\hline $\begin{array}{l}\text { Use of body arts help to } \\
\text { reduce unemployment }\end{array}$ & 98 & 82 & 12 & 10 & 10 & 8 \\
\hline
\end{tabular}

Source: Field study (2019), n-220.

know of this. Ninety-eight (98) of them representing $82 \%$ agreed that use of body arts helps to reduce unemployment, but 12 representing 10\% disagreed and 10 of them also said they do not know whether body arts helps to reduce unemployment or not. Up to half of all body piercings lead to acute infections which require medical treatment, and there have been two piercing-related deaths in Europe this year, the commission said. It added that precious little was known about the chemical structure and toxicity of many of the dyes used in tattooing and warned that many people were effectively injecting car paint into their skins (Quist, 2008).

In summary, the results of the study have revealed that the majority of the respondents (95\%) said that Ewes are concerned about the cultural impacts of body arts, $68 \%$ disagreed that Ewes opt for sustainable body arts instead of low-cost ones, $79 \%$ said Ewes put high priority on body arts development, 80\% said Ewes neglect foreign body art styles that can negatively impact on the youth and $92 \%$ said Ewes prioritize ethical body art styles. Regarding the health risks associated with body arts, it was found that $97 \%$ stated that body decorating can lead to body cancer and allergic reaction, $83 \%$ agreed that body arts can cause pain and excessive bleeding, 95\% said body arts can cause nerve damage, $68 \%$ said body arts can cause life-threatening bacterial infections and 79\% indicated that body arts can lead to blood-borne virus infections like Hepatitis B and HIV. Finally, the study found out that $99 \%$ of the youth agreed that body arts adds beauty to the individual, $96 \%$ agreed that use of body arts helps to preserve the rich Voltarian culture, 70\% agreed that the use of body arts builds self-esteem, and $82 \%$ agreed that the practice of body arts helps to reduce unemployment.

\section{Discussion}

The majority of the respondents agreed that Ewes are concerned about the cultural and moral impact of body arts, Ewes opt for sustainable body arts instead of low-cost ones, Ewes put high priority on body arts development and that Ewes neglect foreign body art styles that can negatively impact on the youth. This shows that there is high awareness of the forms of body arts in the Volta 
Region of Ghana especially the youth. The number of young adults acquiring body arts has increased in recent years. In fact, body arts may now be considered a mainstream activity among older adolescents and young adults in Western societies (Moldre, 2014). In a survey of over 300 youths, Moldre (2014) found that $81 \%$ of the participants reported currently or previously having a body art. In a survey of 500 students in Senegal, Diallo (2015) found that 72 participants currently had a body art. Furthermore, young adults with body arts tend to perceive their anatomic site with arts as more acceptable to the general public than other youths (Gold, 2016). Gold (2016) surveyed 225 participants from Canada and found that $45 \%$ to $62 \%$ of the participants endorsed most body art sites as "accepted by the general public" with the exception of nipple and genital sites, which fewer than $10 \%$ of participants endorsed as accepted. His study also found that black participants were more likely to have body arts on their belly and chest and find that particular anatomic site socially acceptable, while white participants were more likely to have art on the arms or nipples and to find those anatomic sites acceptable. Gold (2016) also found that youth with body arts were not only more likely to see their own art site as more socially acceptable, they were also more likely to see their own art site as having less risk of health complications than the alternative piercing sites of others. However, the perceived risk of complications from body arts among the participants was significantly higher than the actual prevalence of complications noted in the study.

As the prevalence of body art has increased, adverse health risks associated with body art have been documented. Common health risks associated with body art include: infection, pain, bleeding, hematoma formation, cyst formation, allergic reaction, hypertrophic scarring, and keloid formation (Musah, 2011). Infection severity ranges from local infections to more extensive, even systemic infections such as osteomyelitis, toxic shock syndrome, and bacteremia. Life-threatening infections as a result of complications associated with body arts include septic arthritis, acute glomerulonephritis, endocarditis, and hepatitis B. Hepatitis $\mathrm{C}$ transmission has also been cited as a potential complication. Though there have been no confirmed cases of human immunodeficiency virus contracted through the use of contaminated body art instruments, experts agree that it is a possibility (Musah, 2011). Case reports have also documented several site-specific health risks from body arts. The most common among these is infection of auricular cartilage. Studies have also noted a potential correlation between body art and other risk-taking behaviors in adolescents and young adults. College students in general have a high and often exaggerated awareness of the potential health risks associated with body arts, perceiving most risks as more likely to occur than is supported by their own experiences and those of their friends. Participants with no body arts were even more likely to overestimate the associated health risks of body arts. This overestimation of potential consequences is consistent with adolescents' typical overestimation of risks in general, especially those risks linked to behaviors with which they have no experience. All the above findings on some of the major health risks associated with body 
arts have confirmed the findings in the current study.

The study found that body arts practices can lead to preserving the rich Voltarian culture, builds self-esteem and above all it can help to reduce unemployment within the Voltarian communities. But body arts can also have an impact on a person's attitudes and moral life. When Delli (2012) surveyed 341 college students in Tanzania, he found statistically significant differences in risk-taking behaviours between men and women with body modifications (e.g., tattoos and arts) versus those without them. Both men and women with body modifications reported more frequent alcohol intoxication and more marijuana use than their "unadorned" counterparts. Braithwaite in his 2011 survey of 860 adolescent detainees described a statistically significant association between body arts and alcohol use.

More recent surveys of adolescents and young adults suggest an even stronger correlation between body piercing and increased risk-taking behaviors. Carroll (2015) surveyed 552 adolescents and young adults (age range, 12 to 22 years) at a medical clinic for military dependents and found that teenagers who participate in tattooing or body arts were significantly more likely to engage in risk-taking behaviours such as drug use and disordered eating behaviors. In addition, subjects with these forms of body art were found to have higher rates of suicidal ideation and suicide attempts than those without. In a 2014 survey of students, Armstrong (2014) found that factors used to describe overall risky behavior were more commonly found among students with body arts when compared with those who had none. A survey of 2180 students conducted by Deschesnes and Eugene (2011) further supports this finding. Their study reported that certain "externalized" risk behaviors were more commonly associated with tattooed and pierced youth than with their unmodified counterparts, including the use of drugs, gang affiliation, school truancy and gambling. Females obtained more body arts and then removed more, usually as upperclassmen. Males and females reported themselves as risk takers at procedure time and currently; however, only $10 \%$ cited deviancy as a reason for the body arts. Further examination of body arts building personal distinctiveness and self-identity to promote their need of uniqueness is suggested.

\section{Conclusion}

The purpose of the study was to assess the general attitudes, cultural and health impacts of body arts on the Ewe youth in the Volta Region of Ghana. The study has shown that cultural factors drive the adoption of body arts among the Ewe youth, though others marginally engage in various forms of body arts for aesthetic purposes. The study contends that a greater section of the Ewe youth has extensive knowledge regarding the cultural and health impacts of body arts. However, knowledge on the safer approaches to body arts must be carried out through well-planned public education programs organized by the Ghana Health Service especially among the youth in Ghana. In the view of the various findings 
that emerged from this study, the following recommendations are made. Clinicians, body art practitioners and other stakeholders should discuss body arts in the context of providing routine anticipatory guidance to adolescents and should educate adolescents about safer body arts strategies to help minimize associated health risks. Also, body art practitioners need to constantly carry out research on safer methods for body arts in order to improve the quality of body art services in the Volta Region and Ghana as a whole. There is also the need for adequate information on the health risks associated with body art among students, mainly among high school and tertiary students. Therefore, adolescents should be targeted for public health education programs. The government of Ghana should establish and equip a regulatory body to handle body arts, tattoos and body piercings professionally to enhance the services in this sector. Given the lack of longitudinal or causal data, it is unclear from the results of our study whether obtaining a body art changed participants' attitudes or affected their knowledge. It is recommended that further research be carried out on this topic using larger sample sizes based on different cultural groups in Ghana.

\section{Acknowledgements}

We sincerely appreciate the wholehearted support of all the Ewe youth who voluntarily shared their views for the study. We are grateful to all the reviewers and senior colleagues who provided constructive and helpful comments that have help improve the scholarliness of this article.

\section{Conflicts of Interest}

The authors declare no conflicts of interest regarding the publication of this paper.

\section{References}

Ankirskiy, A. (2014). Perception of Tattoos: Now and Then. Japan vs. the Western World. Doctoral Dissertation.

Ankrah, K. D. (2015). Ada People: The Traditionalist Dangme People and Their Unique Asafotufiami Festival; 2013. Trip down Memory Lane.

Armstrong, O. G. (2004). Role of Physical Attractiveness in Impression Formation. Psychonomic Science, 19, 241-243. https://doi.org/10.3758/BF03328797

Arndt, A. D., McCombs, G., Tolle, S. L., \& Cox, C. (2017). Why Are Health Care Managers Biased against Hiring Service Providers with Tattoos? Services Marketing Quarterly, 38, 88-99. https://doi.org/10.1080/15332969.2017.1289789

Avruch, K. (2018). Culture \& Conflict Resolution (Vol. 31). US Institute of Peace Press. https://doi.org/10.1007/978-3-030-11795-5_67-1

Barrett, M., \& Aspen, S. (2009). Visible Body Modification in Hiring Practices. Undergraduate Thesis, University of Wisconsin, Madison. http://minds.wisconsin.edu/handle/1793/53198?show=full

Bell, S. (2019). Tattooed: A Participant Observer's Exploration of Meaning. The Journal of American Culture, 22, 53. https://doi.org/10.1111/j.1542-734X.1999.2202_53.x 
Brooks, K. (2017). This Is the Last Generation of Scarification in Africa. Huffpost. https://www.huffingtonpost.com/entry/scarification_n_5850882

Carroll, K. (2015). The Ritual Process: Structure and Anti-Structure. Aldine.

Clerici, R., \& Meggiolaro, S. (2011). The Context of Body Art: Body Piercing and Tattooing among High School Students in a Northeastern Italian Region. SAGE Open, 1, 1-11. https://doi.org/10.1177/2158244011425833

Cullivan, L. (2018). The Meanings behind the Marks: Scarification and the People of Wa. African Diaspora ISPs.

Delli, G. (2012). Symbolic Self-Completion. Erlbaum.

Deschesnes, U., \& Eugene, J. (2011). Articulating Self and Social Structure. In Self and Identity: Psychological Perspectives (pp. 119-132). Wiley. https://doi.org/10.1007/978-94-007-1266-9_7

Diallo, C. (2015). A Vision of Pale Beauty Carries Risks for Senegalese Women. The New York Times.

Ebeheakey, A. K., \& Kquofi, S. (2018). Traditional Body Marks for Beautification among Selected Dangme Groups in Ghana. Asian Research Journal of Arts and Social Sciences, 5, 1-13. https://doi.org/10.9734/ARJASS/2018/39317

Ellis, A. D. (2015). A Picture Is Worth One Thousand Words: Body Art in the Workplace. Employee Responsibilities and Rights Journal, 27, 101-113. https://doi.org/10.1007/s10672-014-9254-1

Ezeibekwe, U. P., Ojedokun, U. A., \& Aderinto, A. A. (2016). Love for Artwork: Tattooing and Piercing among Undergraduate Students of University of Ibadan, Nigeria. African Journal for the Psychological Studies of Social Issues, 19, 87-95.

Falola, T., \& Ngom, F. (2019). Facts, Fiction and African Creative Imagination. Routledge.

Fountain-Jagodzinski, D. L. (2014). The Implications of Body Modifications on the Hiring Process. Albion.

Frings, F. (2014). The Lived Meaning of Free Choice: An Existential-Phenomenological Description of Everyday Consumer Experiences of Contemporary Married Women. Journal of Consumer Research, 17, 346-361. https://doi.org/10.1086/208562

Glover-Thomas, N. (2020). A “Wellbeing” Paradigm: A Concept-Based Study of Body Art and Regulatory Challenges. Laws, 9, 1-21. https://doi.org/10.3390/laws9040022

Gold, F. (2016). Physical Attractiveness and Mental Health. In J. A. Graham, \& A. M. Kligman (Eds.), The Psychology of Cosmetic Treatments (pp. 196-216). Praeger Scientific.

Ibiyemi, V. A. (2014). Tribal Marks in Africa: An Expired Aesthetic Expression. http://wallyvikky.blogspot.com/2014/04/tribal-marks-in-africanexpired.html?m=1

Ibrahim, B. (2018). Scarification: Leaving Your Mark. http://www.travelblog.org/Africa/Ghana/Northern/Tamale/blog-243868.html

Keita, J., \& Grinch, P. (2017). When Beauty Isn't Talent: The Influence of Physical Attractiveness, Attitudes toward Women, and Competence on Impression Formation. Sex Roles, 7, 867. https://doi.org/10.1007/BF00287771

Kohlberg, L. (2014). Development of Moral Character and Moral Ideology. Review of Child Development Research, 1, 381-431.

Korn, L., Bonny-Noach, H., Koren, G., \& Nissanholtz-Gannot, R. (2021). Factors Associated with Medical Complications after Body Art among Israeli Adults: A Retrospective Study. Israel Journal of Health Policy Research, 10, 39. https://doi.org/10.1186/s13584-021-00474-w

Moldre, K. A. (2014). Physical Appearance and Gender-Sociobiological and Sociocultural Perspectives. State University of New York Press. 
Montgomery, B., \& Parks, E. (2014). Current Responses to Sexual Grooming: Implication for Prevention. The Howard Journal, 46, 60-71.

https://doi.org/10.1111/j.1468-2311.2007.00454.x

Murano, G. (2014). Most Extreme Cultural Body Modifications.

Musah, E. (2011). Physical Attractiveness. Advances in Experimental Social Psychology, 7, 45-56.

Ozongwu, M. (2013). Tribal Marks - The Fading of the "African Tattoo". https://masharikiradio.wordpress.com/2013/05/04/tribal-marks-the-fading-of-the-afric an-tattoo/

Parra, F., Amado, R., Lambertucci, J., Rochac, J., Antunes, C., \& Pena, S. (2013). Colour and Genomic Ancestry in Brazilians. Proceedings of the National Academy of Sciences, 100, 177-182. https://doi.org/10.1073/pnas.0126614100

Punch, K. F. (2013). Introduction o social research quantitative and qualitative approaches. SAGE, London.

Quist, O. (2008). Sex and Relationship Affect Social Self-Grooming. Journal of Nonverbal Behaviour, 7, 183-189.

Quist, O. (2015). Beauty, Productivity, and Discrimination: Lawyers' Looks and Lucre. Journal of Labor Economics, 16, 172-201. https://doi.org/10.1086/209886

Schildkrout, E. (2001). Body Art as Visual Language. AnthroNotes, Winter 2001, 1-3. https://doi.org/10.5479/10088/22380

Shwarz, Y. (2011). Postmodernism, Consumer Culture and the Society of the Spectacle. Advances in Consumer Research, 19, 199-202.

Statista (2015). Survey on the Perception of People with Tattoos in the U.S. https://www.statista.com/statistics/512244/qualities-tattoos-acquired-usa

Stirn, V. (2013). Beauty in the Classroom: Instructor's Pulchritude and Putative Pedagogical Productivity. Economics of Education Review, 24, 369-376. https://doi.org/10.1016/j.econedurev.2004.07.013

Summers, J. K., Howe, M., McElroy, J. C., Ronald Buckley, M., Pahng, P., \& Cortes, M. S. (2018). A Typology of Stigma within Organisations: Access and Treatment Effects. Journal of Organizational Behavior, 39, 1-16. https://doi.org/10.1002/job.2279

Timming, A. R. (2015). Visible Tattoos in the Service Sector: A New Challenge to Recruitment and Selection. Work, Employment \& Society, 29, 60-78.

https://doi.org/10.1177/0950017014528402

Timming, A. R., \& Perrett, D. I. (2017). An Experimental Study of the Effects of Tattoo Genre on Perceived Trustworthiness: Not All Tattoos Are Created Equal. Journal of Trust Research, 7, 115-128. https://doi.org/10.1080/21515581.2017.1289847

Tokyo Times (2013). Japan Learns to Accept Tattoos Despite Connection to Yakuza. Tokyo Times.

https://www.tokyotimes.com/japan-must-learn-to-accept-tattoos-despite-connection-t o-yakuza

Totten, J. W., Lipscomb, T. J., \& Jones, M. A. (2009). Attitudes toward and Stereotypes of Persons with Body Art: Implications for Marketing Management. Academy of Marketing Studies Journal, 13, 77.

Uzobu, E., Olumu, M. O., \& Ayinmoro, D. A. (2014). The Role of Indigenous Scarification and Body Marks in Traditional Medicine among the People of Bayelsa in the South-South Zone, Nigeria. International Journal of Humanities and Social Science Invention, 3, 36-43. 